\title{
EFFECTS OF PRESERVATIVE TREATMENTS ON THE MICROBIOLOGICAL AND STORAGE QUALITY OF TIGER NUT MILK DRINK
}

\author{
Olofu A. Victor, Adeshina O. Gbonjubola, Olayinka O. Busayo \\ Department of Pharmaceutical Microbiology, Ahmadu Bello University, \\ Zaria, Kaduna State, Nigeria \\ Mshelia M. Bata \\ Department of Microbiology, Faculty of Science, Federal University, \\ Birnin Kebbi, Kebbi State, Nigeria
}

\begin{abstract}
Tiger nut milk drink is a milk-like aqueous extract from tiger nut, which is highly nutritious and is consumed in most parts of the world especially in the Northern part of Nigeria. However, its availability is limited due to its short shelf life. The aim of this present study was to determine the effects of preservatives treatments on the microbiological and storage quality of tiger nut milk drink. Fresh tiger nut milk drink was produced according to the standard procedure with portable water and also with sterile distilled water. The milk was divided into 16 aliquots, kept in a sterile container for analysis of the different treatments, and preservatives were added according to the experimental design. The color, odor and consistency of the milk were observed daily for a period of seven days. The total bacteria count (TBC), total coliform count (TCC), total Staphylococcal count (TSC) and total fungi count (TFC) (yeast and mold) were evaluated every two days to monitor the microbial stability. Fresh tiger nut milk without any treatment spoiled within few hours after production, while the aliquot supplemented with all the preservatives; pasteurized and then stored under refrigerated temperature for up to seven days. The range of total bacterial count was from $8.00 \times 10^{4}-1.20 \times 10^{7}$ $\mathrm{CFU} / \mathrm{ml}$. The most prevalent bacterial isolates were; Escherichia coli (17.79\%), Staphylococcus aureus (10.53\%) and Micrococcus spp. (9.78\%), whereas the dominant fungi were Candida tropicalis (16.27\%), Saccharomyces spp. (11.63\%) and Aspergillus spp. (11.63\%). This study showed that tiger nut milk drink has a rich microbial content which affects its shelf life and the addition
\end{abstract}

of natural (spices) and chemical preservatives is important to stabilize the drink; thus there is an urgent need to standardize the use of preservatives.

Keywords: Preservative, treatments, tiger nut milk drink, microbiological, storage quality

\section{INTRODUCTION}

Tiger nuts are sweet nut-like-vegetable root tubers of the perennial grass-like cyperaceous plant called Cyperus esculentus L (Oke et al., 2019). Tiger nuts are rich in carbohydrate, lipids, fiber, proteins, minerals, ascorbic acids and $\alpha$-tocopherols (Ekeanyanwu and Ononogbu, 2010). To exploit their nutritional potential, tiger nuts have been experimented for enriching the fiber content in gluten free bread and biscuits (Zahra and Ahmed, 2014; Aguilar et al., 2015). The process of producing milklike aqueous extracts from tiger nuts, called tiger nut milk, (TNM) or composites with other vegetable milk extracts for beverage was explored by few authors (Belewu, 2007; Ukwuru and Ogbodo, 2011, Udeozor, 2012, Oke et al., 2019).

The consumption and safety of non-carbonated drinks has become increasingly important and demand largely based on their value, flavour, aroma and colour. However, despite the increasing popularity of drinks made from plant origin, the storage stability and microbiological safety calls for concern (Ben-Nwadiba et al., 2005; Eke-Ejorfor and Awaji, 2019). Tiger nut drinks are highly nutritious for human consumption, but limited by the short shelf 


\section{International Journal of Engineering Applied Sciences and Technology, 2021 Vol. 5, Issue 11, ISSN No. 2455-2143, Pages 102-110 \\ Published Online March 2021 in IJEAST (http://www.ijeast.com)}

life which may be as a result of the hygiene involved during preparation, packaging, storage and distribution which may expose it to microbial contamination. The drink was also shown to contain sufficient nutrients that can support microbial growth and subsequent spoilage. Several factors encourage, prevent or limit the growth of microorganisms in drinks.

Varieties of microbes find their way into foods; introduced from the soil in which they were grown, and during harvest, packaging, storage and handling (Netser et al., 2004). Maduka and Ire, (2019) reported that the lack of effective antimicrobial treatments at any step from planting to consumption suggested that pathogens introduced at any point may be present on the final food product. A study carried out by Nyarko et al., (2011) reported the isolation of micro-organisms in tiger nut milk where a total of seven different bacteria with varied frequencies of occurrence were revealed; the most predominant species were E. coli and Bacillus spp. Badau et al., (2018) reported Candida albicans, Saccharomyces cerevisae and Rhizopus oryzae. Growth of fungi occurs over a wide range of temperature and $\mathrm{pH}$ and some of the fungi can produce mycotoxins which can cause mycotoxicosis in humans (Umar et al., 2014). As reported by Obinna-Echem et al., (2019), the threat posed by diseases spread through contaminated food is well known and the epidemiological impact of such diseases is considerable. The presence of pathogenic microorganisms in beverages developed from under-utilized crops can emerge as a major public health concern especially for consumers.

The preservative effect of spices has been previously reported with particular reference to ginger and others (Wood and Pittler, 2000; Ben-Nwadiba, 2005; Nwobosi et al., 2013; Kayode et al., 2017 and EkeEjorfor and Awaji, 2019). The antioxidant properties of spices have also been recognized and demonstrated. Spices effectively increased the antioxidant capacity of foods with their effect's dependent on food matrices (Kayode et al., 2017). Other spices like garlic (Allium sativa) has also been shown to inhibit enzymes involved in lipid synthesis, decrease platelet aggregation, prevent lipid peroxidation of oxidized erythrocytes and lowdensity lipoprotein (LDL), increase antioxidant status, and inhibit angiotensin converting enzyme (Eke-Ejorfor and Awaji, 2019). Garlic reduces cholesterol, reduces blood pressure, and increases antioxidant status (Khalid, 2015). This present study was intended to formulate preservative treatments to lengthen the shelf-life of Tiger nut milk drink being well consumed beverage in Nigeria especially the Northern parts of the country.

\section{MATERIALS AND METHODS}

\subsection{Materials}

Tiger nut tubers (yellow and brown varieties) were purchased from Samaru market, Zaria, Nigeria. The spices including; ginger, cloves, dates, honey which were added as natural preservatives and coconuts were purchased from Sabo market, Zaria, Kaduna State, Nigeria.

\subsection{Chemicals}

The chemicals used include Crystal violet, Lugol's iodine, Acetone, Hydrogen peroxide, sterile deionized water, Hydrochloride acid, Ethanol-acetone, oil immersion, Normal saline, Lactophenol cotton blue stain and Sodium benzoate (chemical preservative).

\subsection{Sample Preparation}

Fresh tiger nut was purchased from the market, and authenticated in the Herbarium Sectionof the Department of Botany, ABU, Zaria. Tiger nut milk was extracted using the method of Udeozor 2012). Tiger nuts were sorted to remove dirt particles and spoilt nuts, washed with sterile distilled water. The nuts were then soaked for $12 \mathrm{~h}$ in sterile water at ambient temperature to soften the seed, blanched at $70^{\circ} \mathrm{C}$ for $5 \mathrm{~min}$ in order to inactivate enzymes that would likely cause clumping after extraction. One kilogram $(1 \mathrm{~kg})$ of the nuts was then wet milled with $1000 \mathrm{ml}$ of sterile water using a sterile laboratory blender and sieved under (stainless sieve $0.01 \mathrm{~mm}$ diameter) with about $2000 \mathrm{ml}$ of sterile water forming the tiger nut milk $(1: 2 \mathrm{w} / \mathrm{v}$, tiger nut versus water). The drink was also produced separately with potable water.

The main additives for the commercial production of tiger nut milk drink were coconut, dates, sugar and ginger. The drink was divided into four portions, and then the additives were individually added. This step was carried out to ascertain the microbiological quality of the starting materials before inclusion of the natural and chemical preservatives. The natural preservatives (spices) used include ginger, clove, honey and dates. While the chemical preservative used was sodium benzoate. 


\section{International Journal of Engineering Applied Sciences and Technology, 2021 \\ Vol. 5, Issue 11, ISSN No. 2455-2143, Pages 102-110 \\ Published Online March 2021 in IJEAST (http://www.ijeast.com)}

\subsection{Experimental design}

Fresh tiger nuts milk was produced and kept in a sterile container for 30 minutes. About $1 \mathrm{~g}$ of the preservatives was dissolved individually in $15 \mathrm{ml}$ of the prepared tiger nut milk, and then subjected to the following treatments. The experiments were carried out with both varieties of tiger nut (brown and yellow varieties), and preparation was made using portable water and sterile distilled water separately.

The microbial contamination level was ascertained for the following treatments:

$>$ Tiger nut milk drinks alone;

$>$ Tiger nut milk with coconut;

$>$ Tiger nut milk with dates;

$>$ Tiger nut milk with ginger;

> Tiger nut milk drink with coconut, dates, sugar and ginger.

The prepared fresh tiger nut milk was divided into 16 different portions to add the different preservatives and other treatments in a sterile bijou bottle for analysis:

$>$ Fresh tiger nut milk without treatment at room temperature (FTMR).

$>$ Fresh tiger nut milk without treatment at refrigerated temperature $\left(\mathrm{FTMR}_{\mathrm{f}}\right)$

$>$ Pasteurized tiger nut milk (PTNM)

$>$ Autoclaved tiger nut milk (ATNM)

$>$ Tiger nut milk treated with ginger (TNMG)

Tiger nut milk treated with cloves (TNMC)

$>$ Tiger nut milk treated with honey (TNMH)

$>$ Tiger nut milk treated with sugar (TNMS)

$>$ Tiger nut milk treated with dates (TNMD)

$>$ Tiger nut milk treated with sodium benzoates $\left(\mathrm{TNMS}_{\mathrm{B}}\right)$

$>$ Tiger nut milk treated with cloves, ginger, honey, sugar and sodium benzoate kept at room temperature $\left(\mathrm{TNMA}_{\mathrm{R}}\right)$
$>$ Tiger nut milk treated with cloves, ginger, honey, sugar and sodium benzoate kept at refrigerated temperature $\left(\mathrm{TNMA}_{\mathrm{RT}}\right)$

$>$ Tiger nut milk treated with cloves, ginger, honey and pasteurized sugar $\left(\mathrm{TNMA}_{\mathrm{P}}\right)$

> Tiger nut milk sterilized (with autoclave) with the addition of cloves, ginger, honey, sugar and sodium benzoate (TNMA)

$>$ Tiger nut milk treated with cloves, ginger, honey, and sugar kept at $27^{\circ} \mathrm{C}$ kept for 7-12 days. $\left(\mathrm{TNMN}_{\mathrm{R}}\right)$

$>$ Tiger nut milk treated with cloves, ginger, honey, sugar, kept at $27^{\circ} \mathrm{C}\left(\mathrm{TNMN}_{\mathrm{F}}\right)$

\subsection{Observation of the storage properties}

The different treatments were analyzed through observing the colour, taste, consistency and general appearance initially and after each day for seven days according to the experimental design.

\subsection{Microbial analysis}

\subsubsection{Plate count}

The microbial contamination level was determined using the plate count technique as described by Eke-Ejiofor and Awaji, (2019). An aliquot of $1 \mathrm{ml}$ of each sample was introduced individually into a bijou bottle containing $9 \mathrm{ml}$ of sterile distilled water to form a stock solution. A fivefold serial dilution was carried out. The plate count was done using the following media:

a. Nutrient agar medium for total bacterial count

b. MacConkey agar for total coliform count

c. Manitol salt agar for total Staphylococcal count

d. Sabouraud dextrose agar for total fungal count

The spread plate method was use. One $\mathrm{ml}$ of the sample was spread over the surface of each medium using a sterile spreader. The plates were incubated at $35^{\circ} \mathrm{C}$ for $24 \mathrm{~h}$ for the bacteria count and $48 \mathrm{~h}$ for fungi count. The number of colonies was counted and then multiplied with dilution factor to evaluate the number $\mathrm{cfu} / \mathrm{ml}$. 


\section{International Journal of Engineering Applied Sciences and Technology, 2021 \\ Vol. 5, Issue 11, ISSN No. 2455-2143, Pages 102-110 \\ Published Online March 2021 in IJEAST (http://www.ijeast.com)}

\subsubsection{Isolation and identification of bacteria}

Distinct isolates were selected from the plate counts media and were purified by sub-culturing aseptically on a nutrient agar media. The process was repeated thrice to purify the isolates. The isolates were Gram stained as described by Cheesbrough (2006). Biochemical tests (catalase, coagulase, oxidase, mannitol fermentation, motility and bile solubility) were carried out to help in the identification of the isolates (Cheesbrough, 2006). Confirmation of Gram negative rods was done using the Microbact Gramnegative identification System 12A \& 24E (Oxoid, U.K) for Enterobacteriaceae and miscellenous Gram negative bacilli.

\subsubsection{Isolation and identification of fungi}

Isolates were selected randomly from the Sabouraud Dextrose Agar plates after taking counts and subcultured aseptically on Sabouraud Dextrose Agar for $48 \mathrm{~h}$. The process was repeated thrice to obtain pure isolates. An essential feature of fungal identification is the microscopic characteristics of the isolates using the Tease mount preparation. The mount was carefully examined under the microscope for the characteristic shapes and arrangements of the spores, hyphae, budding yeasts etc. according to James and Natalie, (2001); Zafar, (2017).

\subsection{Statistical analysis}

All data was entered using Microsoft Office Excel Version 2016 and Statistical Package for Social Sciences (SPSS) Version 20 was used to carry out analysis.

\section{RESULTS}

The different aliquots of the tiger nut milk drinks were analyzed on a daily, based on their organoleptic properties (taste, smell, appearance and consistency) to group them as fresh and spoilt and their sensory shelf-life were ascertained as shown in the charts below.

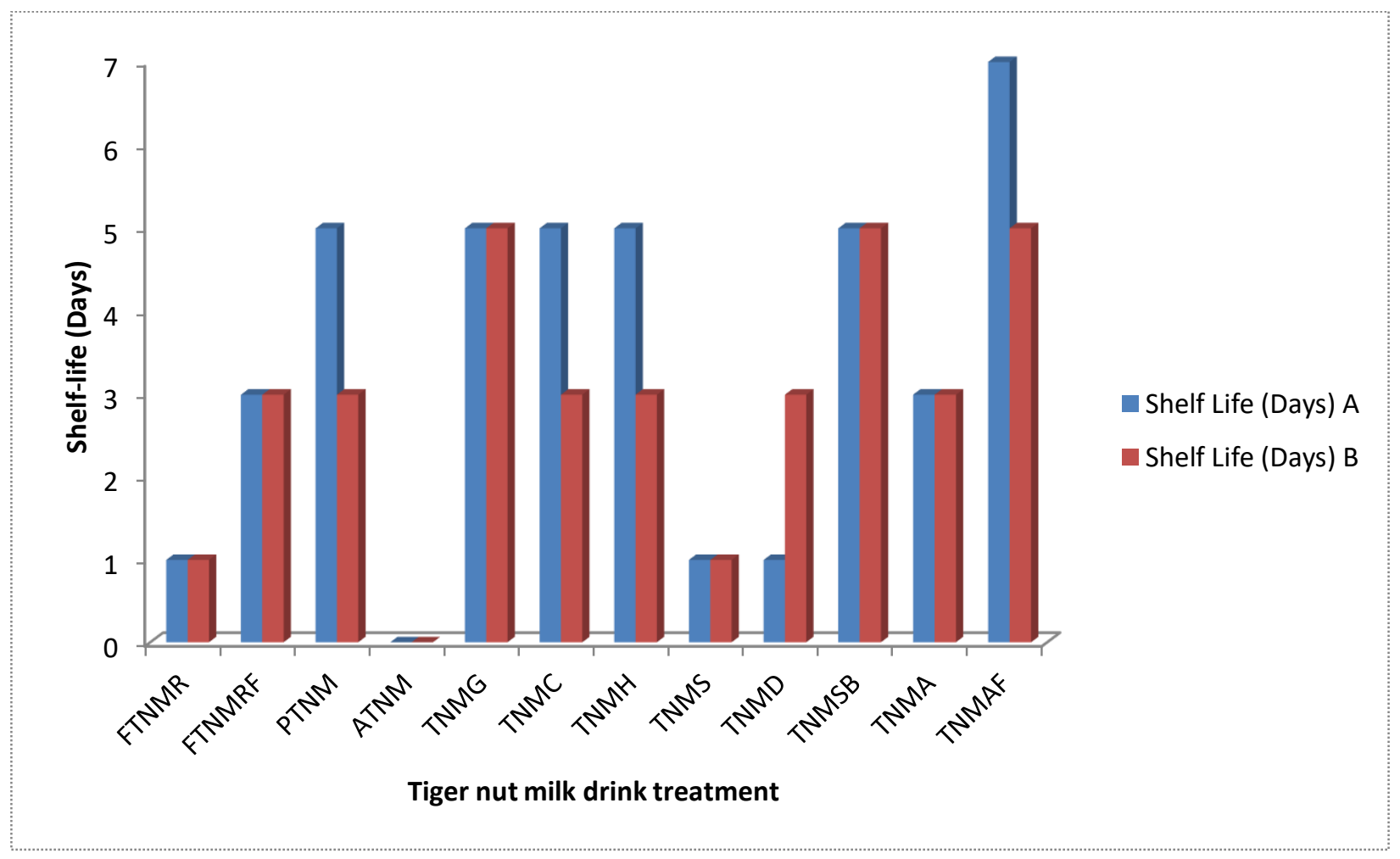

Key: A= Tiger Nut Milk Drink made with the Brown variety of Tiger Nut tuber with portable water $\mathrm{B}=$ Tiger Nut Milk Drink made with the Yellow variety of Tiger Nut tuber with portable water 


\section{International Journal of Engineering Applied Sciences and Technology, 2021 \\ Vol. 5, Issue 11, ISSN No. 2455-2143, Pages 102-110 \\ Published Online March 2021 in IJEAST (http://www.ijeast.com)}

Figure 1: Comparing the Sensory Shelf life of Tiger Nut Milks with different Treatments made from the Brown and Yellow Varieties.

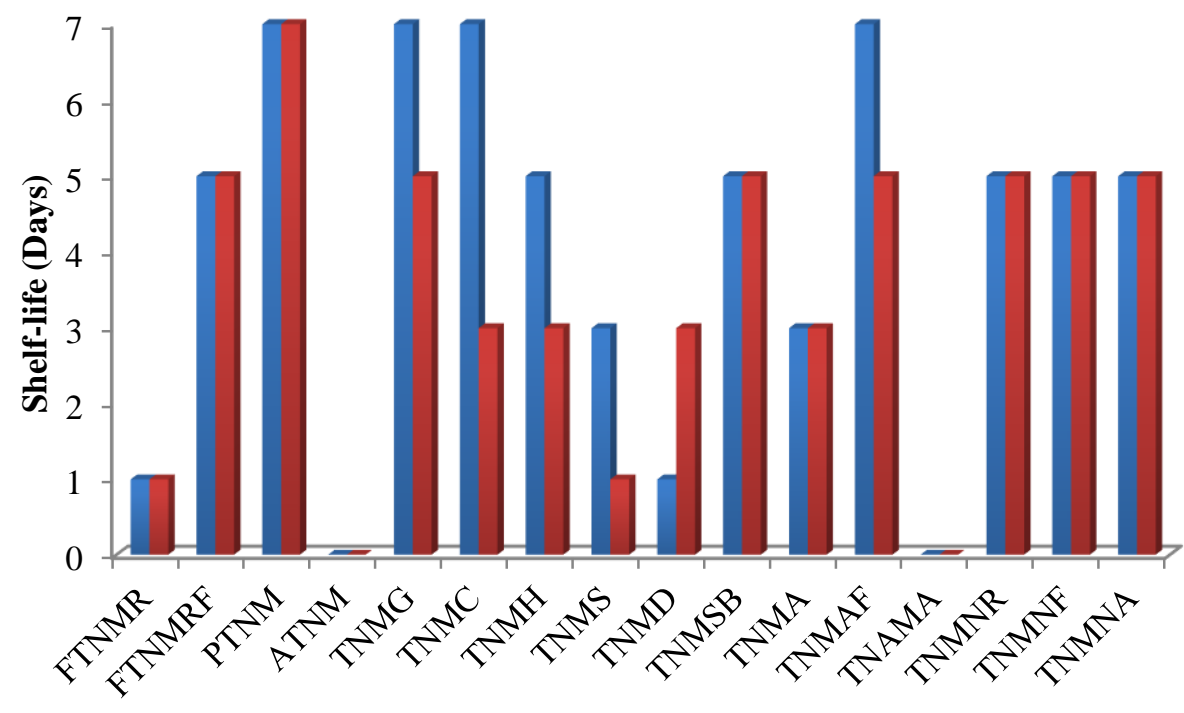

- Shelf Life (Days) C

$\square$ Shelf Life (Days) D

The different tiger nut milk drink treatment

Key: $\mathrm{C}=$ Tiger Nut Milk Drink made with the Brown variety of Tiger Nut tuber with sterile distilled water

$\mathrm{D}=$ Tiger Nut Milk Drink made with the Yellow variety of Tiger Nut tuber with sterile distilled water.

Figure 2: Comparing the Sensory Shelf life of Tiger Nut Milks with different Treatments made from the Brown and Yellow Varieties with Distilled Water.

Table 1: Comparing the efficacy of the different varieties of tiger nut used and the water source

\begin{tabular}{llllllll}
\hline & TBC & TCC & TSC & TFC & $\begin{array}{l}\text { F- } \\
\text { Va } \\
\text { lue }\end{array}$ & $\begin{array}{l}\text { P- } \\
\text { val } \\
\text { ue }\end{array}$ & $\begin{array}{l}\text { L } \\
\text { O }\end{array}$ \\
\hline TB & 9.62 & 2.50 & 5.60 & 2.28 & 2.1 & 0.2 & S \\
PW & $\times 10^{6}$ & $\times 10^{5}$ & $\times 10^{4}$ & $\times 10^{3}$ & 3 & 1 & \\
TY & 7.17 & 1.06 & 4.48 & 3.47 & 7.8 & 0.1 & S \\
PW & $\times 10^{6}$ & $\times 10^{5}$ & $\times 10^{4}$ & $\times 10^{3}$ & 2 & 5 & \\
TB & 1.09 & 2.55 & 1.88 & 2.67 & 2.6 & 0.1 & S \\
SD & $\times 10^{6}$ & $\times 10^{4}$ & $\times 10^{4}$ & $\times 10^{4}$ & 25 & 25 & \\
TY & 3.69 & 2.63 & 1.40 & 4.60 & 2.1 & 0.1 & S \\
SD & $\times 10^{6}$ & $\times 10^{4}$ & $\times 10^{4}$ & $\times 10^{2}$ & 39 & 79 & \\
\hline
\end{tabular}

TBPW: Tiger nut milk drink made with brown variety with portable water

TYPW: Tiger nut milk drink made with yellow variety with portable water

TBSD: Tiger nut milk drink made with brown variety with sterile distilled water

TYSD: Tiger nut milk drink made with yellow variety with sterile distilled water
LOS: Level of significance

F: F-Value (ratio of two sample variances)

TBC: Total Bacteria Count;

TSC: Total Staphylococci Count;

TCC: Total Coliform Count;

TFC: Total Fungi Count.

Table 2: Comparing the efficacy of the different varieties of tiger nut used and the preservatives

\begin{tabular}{lllll}
\hline Treatment & TBC & F & $\begin{array}{l}\text { P- } \\
\text { value }\end{array}$ & LOS \\
\hline FTMR & $1.19 \times 10^{7}$ & 1.942 & 0.299 & $\mathrm{~S}$ \\
FTMR $_{\mathrm{F}}$ & $5.06 \times 10^{6}$ & 0.078 & 0.806 & $\mathrm{~S}$ \\
ATNM & $4.50 \times 10^{5}$ & 0.495 & 0.554 & $\mathrm{~S}$ \\
PTNM & $1.60 \times 10^{6}$ & 1.340 & 0.432 & $\mathrm{~S}$ \\
TNMG & $8.28 \times 10^{6}$ & 1.644 & 0.328 & $\mathrm{NS}$ \\
TNMC & $4.90 \times 10^{6}$ & 3.658 & 0.003 & $\mathrm{NS}$ \\
TNMH & $3.30 \times 10^{6}$ & 24.113 & 0.003 & $\mathrm{NS}$ \\
TNMD & $1.20 \times 10^{7}$ & 1.082 & 0.407 & $\mathrm{~S}$ \\
\hline
\end{tabular}




\begin{tabular}{lllll}
\hline TNMS $_{\text {TNMS }}$ & $1.51 \times 10^{7}$ & 0.645 & 0.506 & $\mathrm{~S}$ \\
TNMA $_{\text {TNMA }}$ & $4.50 \times 10^{6}$ & 1.082 & 0.407 & $\mathrm{~S}$ \\
TNAMA $_{\mathrm{R}}$ & $3.10 \times 10^{6}$ & 4.914 & 0.157 & $\mathrm{~S}$ \\
TNAMN & $9.10 \times 10^{6}$ & 0.405 & 0.590 & $\mathrm{~S}$ \\
TNMNF & $4.70 \times 10^{6}$ & 0.771 & 0.610 & $\mathrm{~S}$ \\
TNMNA & $8.0 \times 10^{6}$ & 0.983 & 1.021 & $\mathrm{~S}$ \\
\hline
\end{tabular}

F: F-Value (ratio of two sample variances);

TBC: Total Bacteria Count;

Sign: Significance; and
LOS: Level of Significance

NS: Not Significant

A total of 133 bacteria were isolated and identified as contaminants of the different tiger nut milk drink consisting of 29 different species with varied frequencies. The top five prevalence bacteria were Escherichia coli (12.8\%), Staphylococcus aureus (10.5\%), Micrococcus spp. (9.8\%), Bacillus spp. (7.5\%), Halfnia alvei (6.0\%) and Enterococcus faecium (5.3\%). Figure 1 below show the distribution of the bacteria contaminants

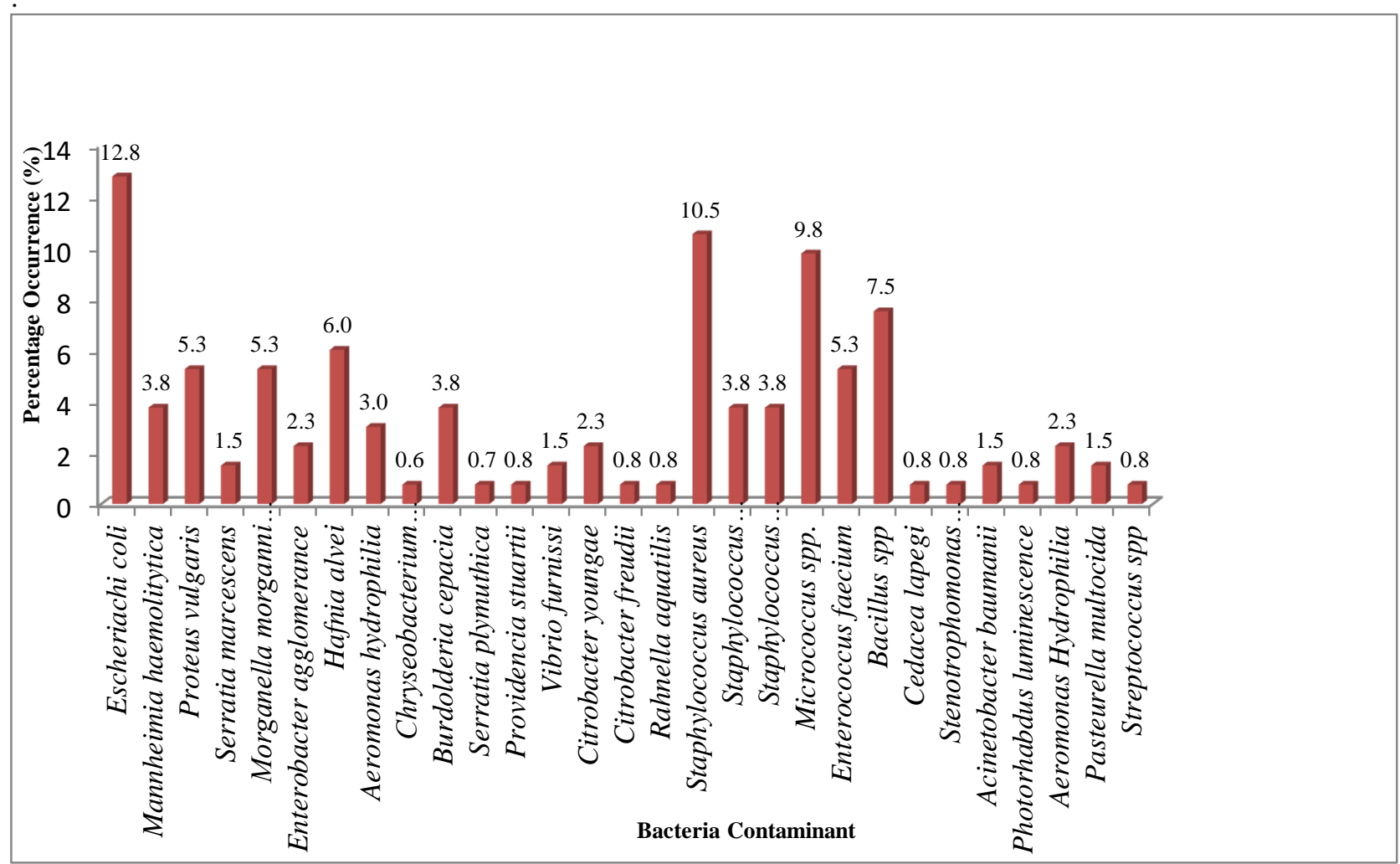

Fig.3: The percentage prevalence of bacteria spp isolated from tiger nut milk drinks

A total of 86 fungi were isolated and identified belonging to 10 different genera. The most frequent organisms identified were Candida tropicalis (16.27\%), Saccharomyces cerevisae (11.63\%),
Aspergillus spp. (11.63\%), Candida albicans (10.47\%), and Penicillium spp. (8.13\%). The percentage distribution of the fungi isolates is shown in the fig. 4 below. 


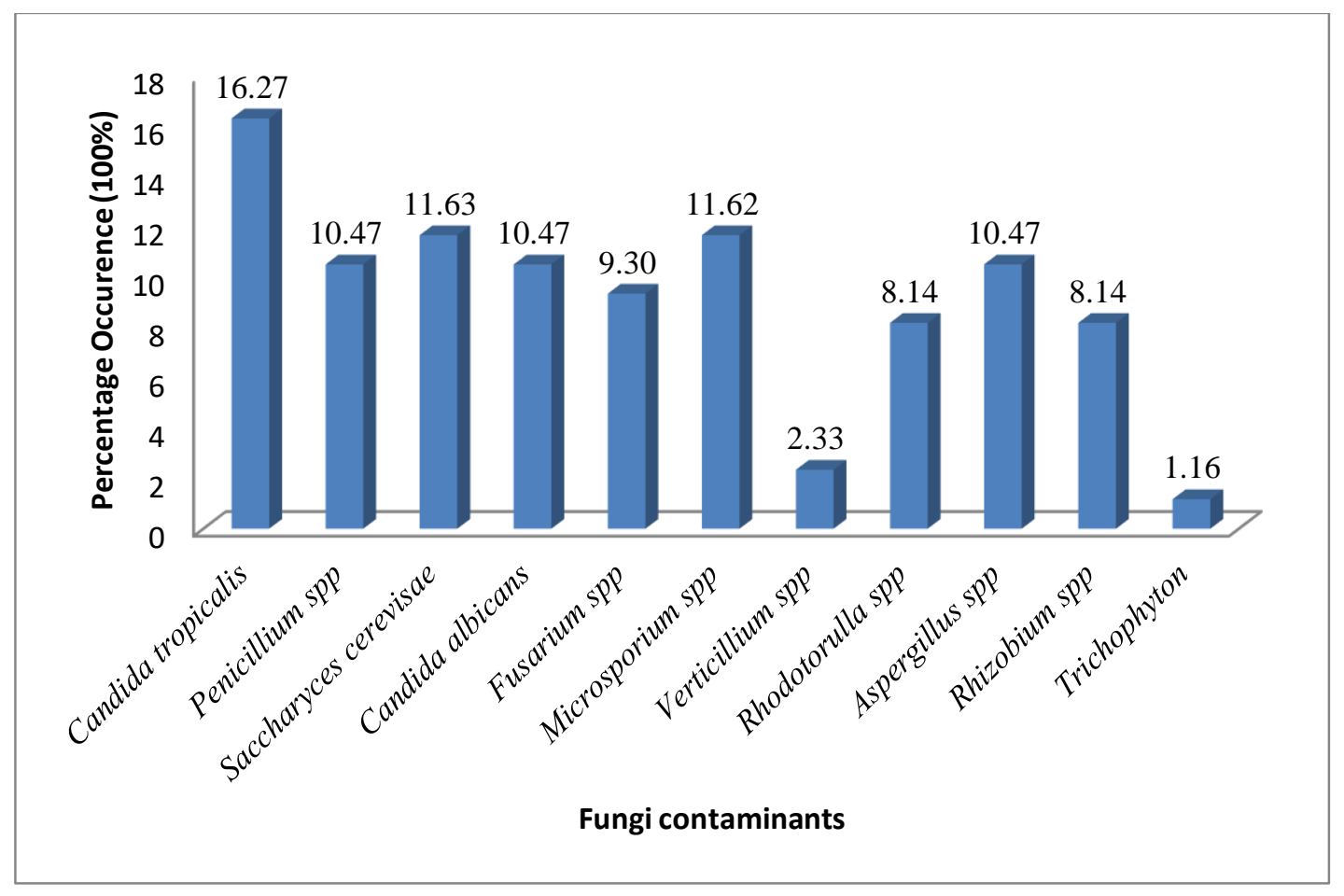

Figure 4: Percentage Distribution of fungi isolated from tiger nut milk drink

\section{DISCUSSION}

From the sensory evaluation of the shelf life, the preservatives have varying effects as well as the quality of the water used. Tiger nuts milk drink produced with sterile distilled water last longer and also the storage condition affects the quality of the milk as the milk got spoiled in less than six hours even with the presence of preservatives and other treatment (pasteurization and sterilization). This study is in agreement with Nwobosi et al., (2013) who reported that at ambient storage, the combinations of natural tropical preservative and refrigerated temperature in addition to citric acid which is an acid regulator and antioxidant was able to offer some inhibition by depression of $\mathrm{pH}$ below the growth range of some microbes at both ambient and refrigerated storage.

The result of this study reveals that tiger nut milk dink produced with portable water have higher amounts of contamination compared to the drinks produced with sterile distilled water. This agrees to the findings of Adeshina et al., (2012) that bacterial contamination of fresh vegetables and fruits can be due to non-availability of quality water in good quantity for washing and pre-disinfection of the fresh vegetables and fruits. Maduka and Ire (2019) reported that microbial contamination of tiger nut milk drink can be due to lack of portable water used in its production. According to Ogechukwu et al., (2016), the use of water polluted with faecal matter to wash knifes, polythene bags, trays could also be a source of contamination of tiger nut tubers.

The variation of the microbial contamination level shows the efficacy of the preservatives and treatment measures used in the production of the tiger nut milk drinks. The tiger nut milk drink kept at ambient temperature shows the highest microbial count. The sterilization of the drink completely eradicates all life forms but destroys the nutritional and sensory qualities of the milk. The result also shows that ginger, clove, honey and sodium benzoate proves effective in the stability of the drink for a period of 57 days at refrigerated temperature. This agrees with findings of Kayode et al., (2017) and Eke-Ejiofor and Awaji, (2019) that spices can be used as preservative to lengthen the shelf-life of tiger nut milk drink.

According to the Microbiological Guidelines for Ready to Eat Food (2014), the total aerobic count of less than $10^{5} \mathrm{CFU} / \mathrm{ml}$ is satisfactory for consumption, $10^{5} \leq 10^{7} \mathrm{CFU} / \mathrm{ml}$ is a borderline for consumption and greater than $<10^{7}$ is unsatisfactory for human consumption. The fresh tiger nut milk drink without treatment kept at room temperature (FTNMR) proves unsatisfactory for human consumption while that 


\section{International Journal of Engineering Applied Sciences and Technology, 2021 Vol. 5, Issue 11, ISSN No. 2455-2143, Pages 102-110 \\ Published Online March 2021 in IJEAST (http://www.ijeast.com)}

preserved with ginger, clove and honey shows border-line for human consumption over the storage period of 9 days. The pasteurized tiger nut milk is satisfactory for consumption as shown in Table 2.

Though there is increasing awareness of the nutritional and medicinal qualities of tiger nut milk drink, the variability of microbial load in the milk is a threat to public health. The top five prevalent bacteria isolated from the milk in this study were Escherichia coli (12.79\%), Staphylococcus aureus (10.53\%), Micrococcus spp. (9.78\%), Bacillus spp. (7.52\%), Hafnia alvei (6.02\%), and Enterococcus spp. $(6.02 \%)$. The result of this study is similar to the findings of Ibrahim et al., (2016) in Sokoto, Nigeria. The most frequent fungi identified were Candida tropicalis (16.27\%), Saccharomyces cerivisae (11.63\%), Aspergillus spp. (11.63\%), Candida albicans (10.47\%), and Pennicilium spp. (10.46). Nura et al., (2016) reported similar result in Jigawa State, in Nigeria while Badau et al., (2018) reported similar findings with varied frequency. This could be due to the source of water, tiger nut and hygiene during production of the drink. The vast variety of fungi isolated is implicated for the quick spoilage of the milk (Maduka and Irene, 2019). Most of the organisms isolated in the drink are implicated for both food spoilage and food-borne diseases (Hubert et al., 2011; Rawat, 2015; Maduka and Irene, 2019). The occurrence of these fungi may cause diverse effects on human health as they have the potential of producing mycotoxins. The concentrations of these substances may increase during storage of tiger nut milk drink due to the increase in the population of the fungal species, hence, daily intake of such tiger nut milk drink containing mycotoxins could result in bioaccumulation in the body which could be hazardous to human health (Nura et al., 2016).

\section{CONCLUSION AND RECOMMENDATION}

The addition of spices as natural preservatives slowed down the multiplication of micro-organism during the storage of Tiger nut milk drink (kunun-aya) at refrigerated condition and hence, made it consumable within the storage period (5 days). The amounts of spices added to the kunun-aya samples were not sufficient to completely inhibit microbial growth and retain the nutritional composition of kunun-aya during the storage period. For this reason, there is need for reformulation and standardization of the ingredients and natural preservatives used in the production of kunun-aya in order to retain or improve the quality during storage and also to encourage commercial scale production.

The ability of microorganisms to contaminate tiger nut milk drink must be examined when evaluating the safety hazards of food poisoning. Safety measures should be taken to reduce or totally remove the occurrence of these microbes in the drink.

\section{REFERENCES}

1. Adeshina G.O., Jibo S.D., and Agu V.E. (2012). Antibacterial Susceptibility Pattern of Pathogenic Bacteria Isolates from Vegetable Salad Sold in Restaurants in Zaria, Nigeria, Journal of Microbiology Research, Vol. 2, No. 2, pp 5-11..

2. Aguilar, N., Albanell, E., Minarro, B., Guamis, B., Capellas, M. (2015). Effect of Tiger NutDerived Products in Gluten-Free Batter and Bread. Food Science and Technology International, Vol. 21, pp. 323-331,.

3. Badau M.H., Bilyaminu D., Ogori A.F., Charles B. and Ogori J. (2018.). Microbial Quality Evaluation of Tiger Nut Beverage (Kunun Aya) Processed and Sold in University of Maiduguri, EC Nutrition, Volume13, Number 3, pp. 138142.

4. Belewu, M.A. and Belewu, K.Y. (2007). Comparative physico-chemical evaluation of tiger-nut, soybean and coconut milk sources, International Journal of Agricultural Biology, Vol. 9, pp. 785-787.

5. Ben-Nwadibia, N. B and Nduku, W. A., (2005). Ethnomedicinal aspects of plants used as spices and condiments in the Niger Delta Area of Nigeria, Nigeria Journal of Herbs, Spices and Medicinal plants, Vol. 16, pp. 81-88.

6. Cheesbrough, M., District Laboratory Practice in Tropical Countries, 2nd ed., Cambridge University Press, New York, pp. 143-179, 2006.

7. Ekeanyanwu R. C. and Ononogbu C. I. (2010). Nutritive value of Nigerian Tiger nut (Cyperus esculentus L.), Agricultural Journal, Vol. 5, No. 5, pp. 297-30.

8. Hubert, D.N., Daniel, N.A.T and Yaw, A. (2011). Assessment of microbiological safety of tiger nuts (Cyperus esculentus. L) in the cape coast metropolis of Ghana, Archives of Applied Science Research, Vol. 3, No. 6, pp. 257-262.

9. Ibrahim S.G., Umar R.A., Isa S.A. and Farouq A.A. (2016). Influence of preservation methods on $\mathrm{pH}$ and microbiological quality of tiger nut (Cyperus esculentus) milk, Bayero Journal of 


\section{International Journal of Engineering Applied Sciences and Technology, 2021 Vol. 5, Issue 11, ISSN No. 2455-2143, Pages 102-110 \\ Published Online March 2021 in IJEAST (http://www.ijeast.com)}

Pure Applied Sciences, Vol. 9, No.2, pp. 234242.

10. James G.C. and Natalie S. Microbiology: A Laboratory Manual (edn.), pp. 211-223.

11. Kayode, R.M., Joseph, J.K., Adegunwa, M.O., Dauda, A.O., Akeem, S.A., Kayode, B.I., Babayeju, A.A. and Olabanji, S.O. (2017). Effects of addition of different spices on the quality attributes of tiger nut milk (Kunun-Aya) during storage, Journal of Microbiology, Biotechnology and Food Sciences, Vol. 7, No.1, pp. 1-6.

12. Khalid I. E., Teham R., Tashioush S. H., Muhammad H. A., Ghaidj R., Petr T., Malek A., "Microbiological status and Nutritional composition of spices used in Food preparation," Food and Nutrition Sciences, Vol. 6, pp. 1134-1140, 2015.

13. Maduka N. and Ire F. S. (2019). A Review of Some Prevention Strategies against Contamination of Cyperus esculentus and Tiger nut- Derived Products of Economic Importance, Asian Journal of Advanced Research and Reports, 3(1): 1-13.

14. Microbiological Guidelines for Food, The Centre for Food Safety, Food and Environmental Hygiene Department, pp. 1-21, 2014.

15. Nester E. W., Anderson D. G., Roberts Jr C. E.., Pearsall N. N., and Nester M. T. (2004) Microbiology: A Human Perspective, 4th Ed., McGraw Hill, London, pp. 801-814.

16. Nguyen V.T., Fagar N., Tumer M.S., and Dykes G.A., (2012). Role of attachment to surfaces on the prevalence and survival of Campylobacter through food systems. Journal of Food Protection, vol. 72, pp. 1885-1890.

17. Nura, M., Abubakar, A., Auyo, M, I., Sunday, E., and Kutama, A. S. (2016). Isolation and Identification of Fungi Associated with Tiger nut Milk Drink (Kunun Aya) In Dutse, Jigawa State. Global Advanced Research Journal of Agricultural Science, vol.5, No. 7, pp. 302-308.

18. Nwobosi P.N.U., Isu NR, Agarry O.O. (2013). Influence of pasteurization and use of natural tropical preservatives on the quality attributes of tiger nut drink during storage. International Journal of Food and Nutrition Science, vol. 2, no. 1, pp. 27-32.

19. Nyarko, D.N., Tagoe, D.N.A. and Aniweh, Y. (2011). Assessment of microbiological safety of tiger nuts (Cyperus esculentus L.) in the Cape Coast Metropolis of Ghana. Archieves of Applied Science Research, vol. 3, no. 6, pp. 257-262.

20. Obinna-Echem P.C., Nkechi J.T, Emelike and Justin M. Udoso (2019). Effect of Packaging Material on the Physicochemical and Microbiological Quality of Refrigerated Tiger Nut Milk (Cyperus esculentus). International Journal of Food Nutrition and Safety, vol. 10, no. 1, pp. 11-25.

21. Oke, E. K, Tijani, A. O, Abamba, R. N, Odumosu, B.O. and Abiola, O.T. (2019). Tiger nut and Its Food Application: A Review. Researcher; vol. 11, no. 1, pp. 73-71.

22. Okechukwu O.J., Orinya C.I., Okonkwo E.O., Uzoh C.V., Ekuma U.O., Ibiam G.A., Onuh E.N. (2016). The microbial contamination of ready-to- eat vended fruits in Abakpa main market, Abakaliki Ebonyi State Nigeria. IOSR Journal of Pharmacy and Biological Sciences; vol. 11 , no.6, pp. 71-80.

23. Rawat Seema (2015). Food Spoilage: Microorganisms and their Prevention. Asian Journal of Plant Science and Research, vol. 5, no. 4, pp. 47-56.

24. Udeozor, L. O. (2012). Tiger nut-Soy Milk Drink: Preparation, Proximate Composition and Sensory Qualities. International Journal of Food and Nutrition Science, vol. 1, no. 4, pp. 18-26.

25. Umar Z.D., Bashir A., Raubilu S.A. (2014). Study on bacteriological quality of kunun aya (Tiger nut Juice) Sold at Umaru Musa Yar'adua University (UMYU) Campus, Katsina”. International Journal of Environment, vol. 3, no. 2, pp. 87-97.

26. Wood C. and Pittler, M. H (2000). Comparison of efficacy of ginger with various anti-motions sickness drugs. British Journal of Anesthesia, vol. 84, no. 3, pp. 367-371.

27. Zafar, A., Jabeen, K., Farooqi J. (2017). Practical Guide and Atlas for the Diagnosis of Fungal Infections.

28. Zahra, S. and Ahmed, M.S.H., (2014). Exploring the suitability of incorporating tiger nut flour as novel ingredient in gluten-free biscuit. Polish Journal of Food and Nutrition Sciences, vol. 64, pp. 27-30. 